\title{
PROBLEM BASED LEARNING TERINTEGRASI PEMBELAJARAN SCIENCE, TECHNOLOGY, ENGINEERING, AND MATHEMATICS (STEM) TERHADAP LITERASI LINGKUNGAN MAHASISWA
}

\author{
Yetti Anita ${ }^{1}$ \\ Muhammad Nur ${ }^{2}$ \\ Muhammad Nasir ${ }^{3}$ \\ 1,2,Pendidikan Biologi Universitas Muhammadiyah Purwokerto \\ E-mail: ${ }^{1}$ Yettianita323@gmail nurstkipprima@gmail.com.com, ${ }^{2}, 3$ muhammadnasir@uniprima.ac.id

\begin{abstract}
This study aims to determine the combined effects of science, technology, engineering, and mathematics (STEM) which is integrated with the problem-based learning $(P B L)$ approach to improve the ability of environmental literacy students in the biological education study program at Puangrimaggalatung University, Sengkang. This research uses the type of Quasi-Experimental research Design using the Noneqivalent Control Group Design research design. This research was conducted at the Biology Education Study Program at Puangrimaggalatung University. The instrument used in this study is the 2018 MSELS (Middle School Environmental Literacy Survey) which has been adopted at several points to adapt to environmental conditions in Indonesia as well as questions relating to environmental change material. The results of the study are known through the $t$-test on the posttest value that is $t$-count $=7.708>t$ table $=4.235$, then $\mathrm{HO}$ is rejected, $\mathrm{HI}$ is accepted, so it shows that there is a difference between the experimental and control classes after being given treatment. This study concludes that problem-based learning models influence the improvement of students' environmental literacy skills in the Biology Education Study Program at Puangrimaggalatung University
\end{abstract}

Kata Kunci :PBL, STEM, Literasi Lingkungan

\section{PENDAHULUAN}

Mahasiswa, dewasa ini memilki kecenderungan yang menjauh dari nilainilai menjaga lingkungan. Kecenderungan tersebut terlihat bahwa mahasiswa semakin konsumtif namun kurang produktif dalam menjaga lingkungan. Menjaga keseimbangan lingkungan merupakan tangung jawab semua orang. Keseimbangan lingkungan dapat tergangu karena kejadian alam dan/atauaktivitas manusia. Ganguan akibat kejadian alam tidak dapat dihindari. Namun ganguan akibat aktivitas manusia masih mungkin untuk dikendalikan. Oleh sebab itu sudah sewajarnya setiap orang memilki wawasan yang baik terhadap lingkungan. Terlebih lagi bagi calon guru yang akan membekalkan wawasan tersebut kepada siswa-siswanya. Dengan demikian, sangat penting untuk mengetahui gambaran wawasan lingkungan mahasiswa calon guru tersebut.

Pelaksanan perkuliahan Pendidikan Lingkungan Hidup di program studi pendidikan biologi Universitas Puangrimagalatung dapat menjadi sarana bagi mahasiswa untuk mengaplikasikan pengetahuan dan mengembangkan ide untuk memperbaiki lingkungan. Kemampuan mengaplikasikan pengetahuan untuk memperbaiki lingkungan adalah bagian 
dari literasi lingkungan, dengan demikian, mata kuliah tersebut tidak hanya memberikan wawasan lingkungan, tetapi juga dapat mengembangkan literasi lingkungan dan kreativitas mahasiswas sehinga diperoleh solusi yang dapat dimanfatkan oleh masyarakat. Namun, dua kemampuantersebut dapat dikembangkan jika cara penyajian mata kuliah Pendidikan Lingkungan Hidup tersebut dipilih dengan tepat.

Literasi lingkungan berfungsi untuk membangun pemahaman mahasiswa terhadap konseputama berdasarkan dan mengaplikasikan pengetahuan untuk memecahkan masalahlingkungan dengan sumber yang tidak dibatasi melalui pemanfatan teknologi. Kemampuan ini memberikan bekal pengetahuan dan cara berpikir yang diperlukan dalam pemecahan masalah global yang berhubungan dengan udara, air, dan hutan (Zuriyani, 2010).

Perkuliahan yang memenuhi kebutuhan capaian pembelajaran pendidikan lingkungan hidup dapat dikemas dalam perkuliahan berbasis STEM. Secara umum implementasi dari STEM dalam perkuliahan dapat mendorong mahasiswa untuk mendesain, mengembangkan dan memanfatkan teknologi, dapat mengasah kognitf,manipulatif dan afektif, sertamengaplikasikan pengetahuan (White, 2014).

Penelitian telah banyak mengungkapkan tentang kegiatan untuk meningkatkan literasi lingkungan mahasiswa. Literasi lingkungan dapat meningkat dengan mengimplementasikan rancangan perkuliahan berbasis masalah, baik mengangkat masalah lokal (Shume, 2016)maupun masalah global. Selain itu, peningkatan literasi lingkungan juga sejalan dengan implementasi rancangan perkuliahan berbasis teknologi (Abrami dkk, 2014; Storksdieck, 2016) dan berbasis inkuiri (Chu dkk., 2011; Vieira \& Tenreiro-Vieira, 2014). Bentukbentuk perkuliahan dengan mengangkat permasalahan lingkungan, dapat mendorong mahasiswa wdwalamw wpemecahan masalah-masalah lingkungan dengan memanfaatkan pengetahuan yang telah dimilikinya. Problem based learning (PBL) memberikan peluang kepada mahasiswa untuk menggunakan pengetahuan pada pemecahan masalah (Jo \& Ku, 2011; Wirkala \& Kuhn, 2011; Mayer dkk., 2012; Sandi-Urena dkk., 2012). Problem based learning sekaligus membantu mahasiswa untuk menguasai pengetahuan yang diperlukan untuk memecahkan masalah lingkungan. Pengetahuan ini dapat berupa informasi atau data yang kemudian digunakan sebagai bahan pertimbangan untuk memilih cara penyelesaian yang tepat. Keputusan ini diperoleh melalui pemikiran yang logis, kritis, dan sistematis.

Penerapan STEM dapat didukung oleh berbagai metode pembelajaran. STEM dapat dintegrasikan dengan berbagai metode pembelajaran dapat digunakan untuk mendukung penerapanya (Becker \& Park, 201). Tujuan pemakaian pembelajaran STEM dalam perkuliahan Pendidikan Lingkungan Hidup adalah untuk mengaktualisasi literasi lingkungan. Kemampuan tersebut 
merupakan kemampuan abad ke-21 yang dapat diakomodasi dengan menerapkan metode PBL dan pembelajaran berbasis proyek (Bel, 2010).

Penelitian tentang integrasi STEM dalam PBL terhadap literasi lingkungan masih jarang dilakukan. Hasil penelitian Farwati dkk., (2017) Mengangkat masalah-masalah lingkungan sangat tepat dilakukan dengan pendekatan problem based learning (PBL). Integrasi PBL dalam STEM sangat memungkinkan mengaktualisasi literasi lingkungan dan kreativitas mahasiswa.

Mahasiswa program studi pendidikan biolog Universitas Puangrimagalatung sebagai calon guru yang akan membekalkan wawasan kepada siswa-siswanya khususnya terkait isu-isu lingkungan diharapkan memilki sikap literasi lingkungan. Mata Kuliah Pendidikan Lingkungan Hidup mengkaji penyelesaian masalahmasalah lingkungan dari berbagai sudut pandang bidang ilmu. Dengan demikian, sangat tepat diselengarakan dengan pendekatan multidisiplin seperti gabungan dari science, technology, enginering, dan mathematics (STEM). Mengangkat masalah-masalah lingkungan sangat epat dilakukan dengan pendekatan problem based learning (PBL). Integrasi PBL dalam STEM sangat memungkinkan mengaktualisasi literasi lingkungan.

\section{METODE}

Penelitaninimengunakanjenispe nelitan Quasi Experimental Design mengunakandesainpenelitanNoneqivale nt Control Group Design.
Penelitaninidilakukan di Prodi PendidikanBiologiUniversitasPuangrim agalatung,

diambilduakelassebagaikelaseksperime ndankelaskontrol. Masingmasingkelasmendapatkanperlakukanyai tukelaseksperimendengan model pembelajaranberbasispemecahanmasala h (PBL), sedangkankelaskontroldengan model pembelajarankonvensional. Instrumen yang digunakandalampenelitaniniadalah

MSELS (MidleSchool Environmental Literacy Survey) tahun 2018 yang telahdiadaptasidibeberapapointuntukme nyesuaikandengankondisilingkungan yang ada di Indonesia sertasoalberkaitandenganmateriperubah anlingkungan. Angket MSELS terdiridariempatindikatoryaitu : 1) Pengetahuanekologi, 2) KeterampilanKognitf, 3) SikapterhadapLingkungandan 4) PerilakukomitmenterhadapLingkungan. Instrumentersebutterdiridaritigabentuks oalyaitu 27 soalpilihanganda, 37 kuesionerdan 4 soaluraian. Total soal yang diberikanpadamahasiswaadalah 68 soal, soaltersebutdigunakanuntukmengukurk emampuanliterasilingkunganmahasiswa

Perlakuanpadakelaseksperimend ankelaskontrolberbeda.

Berikutpenerapan model PBL padakelaseskperimen :

Tahap I, orientasi siswa pada masalah yaitu siswa dihadapkan dengan permasalahan dalam kehidupan seharihari. Permasalahan diberikan pada siswa di dalam Lembar Diskusi Siswa (LDS), LDS yang disusun telah terintegrasi dengan indikator literasi 
lingkungan.

Tahap I, mengorganisasi siswa untuk belajar yaitusiswa membentuk kelompok yang terdiri dari 5-6 orang, lalu guru memberikan LDS yang terintegrasi dengan literasi lingkungan. LDS tersebut membantu siswa meningkatkan kemampuan literasi lingkungan, karena di dalam LDS terdapat pertanyan-pertanyan yang berkaitan dengan empat indikator (delapan sub indikator) literasi lingkungan.

Tahap II, membimbing pengalaman individual atau kelompok yaitu, siswa melakukan investigasi untuk menyelesaikan permasalahan dengan dibimbing oleh guru. Permasalahan yang diberikan pada siswa terdiri atas 4 bagian yaitu sesuai dengan empat indikator (delapan sub indikator) literasi lingkungan yaitu 1) bagian I : kognitf (sub indikator :identifikasi su lingkungan, analisis isu lingkungan, dan rencana aksi lingkungan), 2) bagian I :pengetahuan ekologi (sub indikator :pengetahuan ekolog dasar), 3) bagian II : sikap terhadap lingkungan (sub indikator : niat untuk bertindak, kepekan terhadap lingkungan, dan perasan terhadap lingkungan) dan 4) bagian IV : perilaku (sub indikator :perilaku komitmen terhadap lingkungan).

Tahap IV, mengembangkan dan menyajikan hasil karya yaitu, siswa melakukan presentasi terhadap hasil diskusi dalam meyelesaikan permasalahan.

Tahap V, menganalisis dan mengevaluasi proses pemecahan masalah yaitu Siswa bersama dengan guru menganalisis dan mengevaluasi proses-proses dalam mengatasi masalah serta guru membantu siswa untuk melakukan refleksi terhadap investigasinya serta proses-proses yang mereka gunakan.

Teknik analisis data digunakan untuk mengetahui perbedan literasi lingkungan antarakelas eksperimen dan kelas kontrol mengunakan uji independent sample t-test, dengan taraf signifikasnsi $5 \%$

\section{PEMBAHASAN}

Pengetahuan lingkungan mahasiswa terdiri dari lima indikator yang telah dirumuskan oleh OECD dan NAAEE. Skor rata-rata setiap indikator dari pengetahuan lingkungan secara rinci disajikan pada tabel berikut ini. Tabel 1. Hasil Pretest Kelas Eksperimen Dan Kontrol

\begin{tabular}{|l|l|c|c|}
\hline No & $\begin{array}{l}\text { Aspek Literasi } \\
\text { Lingkungan }\end{array}$ & \multicolumn{2}{|c|}{ Pretest } \\
\cline { 2 - 4 } & $\begin{array}{l}\text { Eksperi } \\
\text { men }\end{array}$ & $\begin{array}{l}\text { Kont } \\
\text { rol }\end{array}$ \\
\hline 2 & $\begin{array}{l}\text { Partisipasi dan } \\
\text { tindakan } \\
\text { strategis }\end{array}$ & 69 & 70 \\
\hline 2 & $\begin{array}{l}\text { Solusi masalah } \\
\text { lingkungan }\end{array}$ & 64 & 64 \\
\hline 3 & Isu Lingkungan & 79 & 79 \\
\hline 4 & $\begin{array}{l}\text { Sistem Budaya, } \\
\text { Sosial dan } \\
\text { Politik }\end{array}$ & 70 & 69 \\
\hline 5 & $\begin{array}{l}\text { Sistem fisik dan } \\
\text { ekologi }\end{array}$ & 61 & 60 \\
\hline \multicolumn{2}{|l|}{ Rata-rata } \\
\hline
\end{tabular}

Pada tabel di atas, hasil rata-rata pretest kemampuan literasi yang terdiri dari aspek partisipasi dan tindakan strategis, solusi masalah lingkungan, isu lingkungan, sistem budaya, sosial dan politik dan sistem fisik dan ekologi pada kelompok eksperimen adalah 68,6, 
sedangkan pada kelompok kontrol 68,4. Mayoritas kedua kelompok percobaan memiliki kategori yang sama pada setiapindikator. Hanya saja pada indikator partisipasi dan tindakan strategis kelas

kontrol emiliki kategori yang lebih tinggi dari pada kelas eksperimen dan pada pada aspek sistem fisik dan ekologi, dan system budaya, social dan politik kelas eksperimen lebih tinggi daripada kelas kontrol.

\begin{tabular}{|c|c|c|c|}
\hline \multirow[t]{2}{*}{ No } & \multirow{2}{*}{$\begin{array}{l}\text { Aspek } \\
\text { Literasi } \\
\text { Lingkun } \\
\text { gan }\end{array}$} & \multicolumn{2}{|c|}{$\begin{array}{c}\text { Rata-rata Hasil } \\
\text { Pretest }\end{array}$} \\
\hline & & $\begin{array}{l}\text { Kelaseksper } \\
\text { imen }\end{array}$ & $\begin{array}{l}\text { Kelas } \\
\text { kontro } \\
1\end{array}$ \\
\hline 1 & $\begin{array}{l}\text { Partisipa } \\
\text { si dan } \\
\text { tindakan } \\
\text { strategis }\end{array}$ & 79 & 71 \\
\hline 2 & $\begin{array}{l}\text { Solusi } \\
\text { masalah } \\
\text { lingkung } \\
\text { an }\end{array}$ & 75 & 64 \\
\hline 3 & $\begin{array}{l}\text { Isu } \\
\text { Lingkun } \\
\text { gan }\end{array}$ & 86 & 81 \\
\hline 4 & $\begin{array}{l}\text { Sistem } \\
\text { Budaya, } \\
\text { Sosial } \\
\text { dan } \\
\text { Politik } \\
\end{array}$ & 81 & 70 \\
\hline 5 & $\begin{array}{l}\text { Sistem } \\
\text { fisik dan } \\
\text { ekologi }\end{array}$ & 78 & 60 \\
\hline Rata & rata & 79,8 & 69,2 \\
\hline
\end{tabular}

Tabel 2 berikut ini menunjukkan ratarata skor posttest kemampuan literasi ekologi kelas eksperimen dan kelas control

Hasil penelitian menemukan bahwa keseluruhan indikator pada kelas eksperimen lebih tinggi daripada kelas control. Terlihap pada rata-rata keseluruhan kelas eksperimen adalah 79,8 sedangkan pada kelas control 69.2.Hasil penelitian menunjukkan perbedaan nilai rata-rata disebabkan karena di dalam kegiatan pembelajaran masing-masing kelas menggunakan model pembelajaran yang berbeda. Menurut Purnamaningrum dkk. (2012) pembelajaran Problem Based Learning merupakan pembelajaran yang dilakukan dengan menghadapkan siswa pada permasalahan yang nyata pada kehidupan sehari-hari, sehingga siswa dapat menyusun pengetahuannya sendiri dalam memecahkan masalah dan mengupayakan berbagai macam solusinya, yang mendorong siswa untuk berpikir kreatif.

$$
\text { Hasil analisis menggunakan }
$$

SPPS 18.0 diketahui bahwa data kelompok eksperimen dan kelompok kontrol berdistribusi normal, homogen dan tidak ada perbedaan rata-rata awal kemampuan literasi ekologi pada kedua kelompok sehingga analisis yang digunakan untuk menguji hipotesis adalah uji statistik dengan uji-t independent pada taraf signifikansi 0,05 atau tingkat kepercayaan 95\%. Tabel t berikut ini menunjukkan uji hipotesis menggunakan uji-t independent

Tabel 3. Hasil Uji Statistik

\begin{tabular}{|l|l|l|l|}
\hline Aspek & $\mathrm{t}$ & $\mathrm{Sig}$ & Keputusan \\
\hline $\begin{array}{l}\text { Literasi } \\
\text { Lingkungan }\end{array}$ & 7,708 & 0.000 & Ho.ditolak \\
\hline
\end{tabular}

Berdasarkan uji hipotesis, diperoleh $\mathrm{t}$ hitung $=7,708>\mathrm{t}$ tabel $=4,235$ dan nilai signifikansi $0,000<0,05$. Maka HO ditolak atau dengan kata lain model problem based learning lebih efektif dari pembelajaran model konvensional 
ditinjau dari kemampuan literasi lingkungan mahasiswa.

Salah satu bagian penting dari pengembangan keterampilan literasi menurut Bybee (2008) adalah literasi lingkungan. Sehingga dari itu, literasi lingkungan termasuk bagian utama dalam pendidikan abad-21 (ELTF, 2015). Berdasarkan temuan dari penelitian ini terdapat beberapa indikator dari masing-masing aspek literasi lingkungan yang menjadi perhatian untuk mengembangkan rencana perkuliahan. Pembelajaran dengan pendekatan multidisiplin berpotensi mendorong mahasiswa untuk menggunakan pengetahuan dari teori hingga praktik untuk menghasilkan pemecahan masalah lingkungan (Scholz, 2011). Salah satu pendekatan multidisiplin yang berpotensi untuk mengembangkan literasi lingkungan mahasiswa yaitu pendekatan pembelajaran yang mengintegrasikan science, technology, engineering, and mathematics (STEM) termasuk pendekatan multidisiplin (Doerschuk dkk., 2016).

\section{KESIMPULAN}

Berdasarkan penelitian yang telah dilakukan di Fakultas Keguruan dan Ilmu Pendidikan Universitas Puangrimaggalatung tentang model pembelajaran berbasis masalah (PBL) terintegras STEM terhadap kemampuan literasi lingkungan mahasiswa dan hasil analisis data, dapat disimpulkan bahwa ada perbedaan kemampuan literasi lingkungan antara kelas eksperimen (menggunakan model pembelajaran berbasis pemecahan masalah) dengan kelas kontrol (tanpa menggunakan model pembelajaran berbasis pemecahan masalah) dengan thitung $=$ $7,708>\mathrm{t}$ tabel $=4,235$.

\section{DAFTAR RUJUKAN}

Abrami, P. C., Wade, C. A., Lysenko, L., Marsh, J., \&Gioko, A. 2014. Using educational technology to develop early literacy skills in Sub-Saharan Africa. Education and Information Technologies, 21, 945-964. doi: 10.1007/s10639-014-9362-4

Becker, K., \& Park, K. 2011. Effects of integrative approaches among Science, Technology, Engineering, and Mathematics (STEM) subjects on students' learning: A preliminary metaanalysis. Journal of STEM Education, 12(5\&6), 23-37.

Bell, S. 2010. Project-based learning for the 21st century: Skills for the future. The Clearing House: A Journal of Educational, 83(2), 39-43.

Chu, S. K. W., Tse, S. K., \& Chow, K. 2011. Using collaborative teaching and inquiry projectbased learning to help primary school students develop information literacy and information skills. Library \& Information Science Research, 33 , 132-143. doi:10.1016/j.lisr.2010.07.017

Farwati, R., Permanasari, A. \&Firman, $\mathrm{H}$. 2015. Studideskriptifmatakuliah Kimia Lingkungan di beberapa LPTK di Indonesia. JurnalPendidikan IPA Indonesia, 4(1), 17. 
Jo, S., \& Ku, J.-O. 2011. Problem based learning using real-time data in Science Education for the gifted. Gifted Education International, 27, 263-273.

Purnamaningrum A., Dwiastuti S. Probosari R. M., danNoviawati. 2012.

PeningkatanKemampuanBerpiki rKreatifMelalui Problem Based Learning (PBL) padaPembelajaranBiologiSiswa Kelas X-10 SMA Negeri 3 Surakarta TahunPelajaran 2011/2012.

PendidikanBiologiUniversitasN egeri Surakarta.

Scholz, R. W. 2011. Environmental literacy in science and society: From knowledge to decisions. Cambridge: Cambridge University Press.

Shume, T. 2016. Teachers' perspectives on contributions of a prairie restoration project to elementary students' environmental literacy. International Journal Of Environmental \& Science Education, 11(12), 5331-5348

White, D. W. 2014. What is STEM education and why is it important?. Florida Association of Teacher Educators Journal, 1(14), 1-9.

Zuriyani, $\quad$ E. 2010.

Literasisainsdanpendidikan

[Online]. Retrieved from http://sumsel.kemenag.go.id/file/fil e/TULISAN/wagj1343099486.pdf 